IRSH 54 (2009), Supplement, pp. 69-90 doi:I0.1017/So02085900999024I

(C) 2009 Internationaal Instituut voor Sociale Geschiedenis

\title{
Working in a Fez Factory in Istanbul in the Late Nineteenth Century: Division of Labour and Networks of Migration Formed along Ethno-Religious Lines
}

\author{
Mustafa ERDEM K A B A AYI* \\ Department of History, Istanbul Bilgi University \\ E-mail: mekabadayi@bilgi.edu.tr
}

SUMMARY: In terms of production volume, most Ottoman state factories cannot be regarded as success stories, yet the labour relations they initiated, engendered, and supervised were important for the emergence of factory labour in the Ottoman Empire and the Turkish republic. One of those state factories was the Imperial Fez Factory, where, throughout the nineteenth century, approximately 500 workers were employed, making it the second highest concentration of industrial workers in the empire after the Imperial Arsenal. Very recently, a limited number of wage ledgers for the fez factory became available for research. Those ledgers provide unprecedented information not only on remuneration but also on the production process and labour-control practices in the fez factory. Those ledgers enable us, for the first time, to formulate research questions within the framework of a broad labour history, in particular for the Ottoman factory workforce in the late nineteenth century. This article examines the effects of the ethno-religious characteristics and gender of Ottoman factory labourers on employment practices and wage-earning at the fez factory.

\section{INTRODUCTION}

This article attempts to assess the ethnic division of labour argument for the late Ottoman industrial workforce at the factory level. The factory examined for the study, the Imperial Fez Factory, ${ }^{\mathrm{I}}$ was one of the major industrial establishments of the Ottoman Empire, initiated, supervised, and run by the state. Even in the late nineteenth century the number of state-owned

\footnotetext{
* This article is based mainly on M. Erdem Kabadayı, "Working for the State in a Factory in Istanbul: The Role of Factory Workers' Ethno-Religious and Gender Characteristics in StateSubject Interaction in the Late Ottoman Empire" (unpublished Ph.D. dissertation, LudwigMaximilian University, Munich, 2008).

I. Feshane-i Amire in Turkish and henceforth simply Feshane.
} 
industrial enterprises and their respective share of total industrial production in the Ottoman Empire were relatively insignificant, for such factories mostly produced clothing for soldiers and public servants. Although the volume of their production was not remarkably high, they were still of fundamental importance to the state, as it was not the quantity of their production that was essential, but rather their key role in providing for the needs of the Ottoman Empire. In the nineteenth century the Ottomans imported large quantities of European textile products, but to clothe and equip their army and navy the Ottoman authorities took a deliberate decision to remain independent of imported goods. That decision led to the founding of many state-owned factories producing textiles to meet military demand during the nineteenth century.

The fact that the state was the employer and the employees were Ottoman subjects provides us with a suitable case study to consider not only industrial labour relations but also the interaction between state and subject in the late Ottoman Empire, and the factors which together determined their interaction, with the focus being especially on the gender and ethno-religious characteristics of Istanbul people working in the factories. Istanbul was a magnet for migrant labour throughout many centuries, so most Istanbul citizens working in industrial establishments in the nineteenth century had not been born there. Where they came from and how they managed to obtain their jobs is the second question which will be examined for the workforce of our chosen factory.

The first thing to note is that gender was the decisive factor in the division of labour and the main determinant of the venue for industrial work at Feshane. Female labourers worked for the factory from their homes, and so took part in a well-organized and closely supervised urban putting-out system. The gender-based division of labour and sexual separation of the shop floor were also common practices in early western European factories, but the female workers of Feshane had another characteristic not shared by European factories: religious segregation, for they were almost all non-Muslim. The majority of the male workforce was Muslim, but Muslim women accounted for only a negligible fraction of the female workforce, so there was a clear gender-religious division of labour. In this article, our analysis will be limited to a consideration of the male component of the factory workforce, and the female workers of Feshane will not be taken into account. ${ }^{2}$

FESHANE

Only a limited number of studies of Ottoman state industrial enterprises are available. If we leave aside some introductory articles, factory production

2. For a detailed analysis of all Feshane workers, see Kabadayı, "Working for the State in a Factory in Istanbul”. 
is one of the unexplored subjects of Ottoman economic and labour history. ${ }^{3}$ One of the rare studies on factory production in Istanbul provides brief but precise information on Feshane, ${ }^{4}$ and from it we learn that Feshane was initially established as a manufactory in Kadirga, a district close to the Old Imperial Palace in Istanbul, from where it was moved in I 833 to Eyüp, on the Golden Horn, the centuries-old industrial zone of Istanbul, where it still stands today. Therefore, it is not surprising that during the nineteenth century there was a high concentration of state industrial enterprises on both shores of the Golden Horn.

Two important features of Feshane set it apart from other state industrial enterprises of its time. First, it was one of the very few state enterprises that outlived the Ottoman Empire, continuing to function as a state factory until 1986, when it was partially demolished and its main production hall was transformed into an exhibition centre and is still known as Feshane. S Second, it was the single Ottoman state factory that competed for customers under free market conditions. The production of the factory was intended to supply the needs not only of the military and public servants, but those of the domestic market too.

\section{ETHNIC DIVISION OF LABOUR?}

The oversimplified notion of an ethnic and religious division of labour has for decades distorted our understanding of Ottoman economic and social history. That has its roots in travelogues and consular reports from the Ottoman Empire throughout the centuries, the views of outsiders introducing and then strengthening the notion that Muslims of the Ottoman Empire where mainly tillers of the soil, while non-Muslims were the ones engaged in the various trades. Although the term "ethnic division of labour" had not yet been coined, that perspective can be found in Ottoman economic history writing from as early as i91 $7 .{ }^{6}$ However, Kirlı provides a brief discussion of the development of the concept of ethnic

3. Tevfik Güran, "Tanzimat Döneminde Devlet Fabrikaları", in Hakkı Dursun Y1ldız (ed.), I50. Yllinda Tanzimat (Ankara, I992), pp. 235-249, and Nikolai Todorov, "The First Factories in the Balkan Provinces of the Ottoman Empire", METU Studies in Development (1971/1972), pp. 315-358. Quataert provides brief information on privately owned textile factories from the last years of the nineteenth century and early years of the twentieth century in Donald Quataert, Ottoman Manufacturing in the Age of the Industrial Revolution (Cambridge, I993), pp. 90-92.

4. Wolfgang Müller-Wiener, "Manufakturen und Fabriken in Istanbul vom I 5.-19. Jahrhundert”, Mitteilungen der Fränkischen Geographischen Gesellschaft, 33/34 (I986/1987), pp. $257-320$.

5. For more information on Feshane today see www.feshane.com.tr [last accessed i 3 April 2009].

6. A.J. Sussnitzki, "Zur Gliederung wirtschaftlicher Arbeit nach Nationalitäten in der Türkei”, Archiv für Wirtschaftsforschung im Orient, 2 (1917), pp. 382-407, cited in Cengiz Kurl, "A 


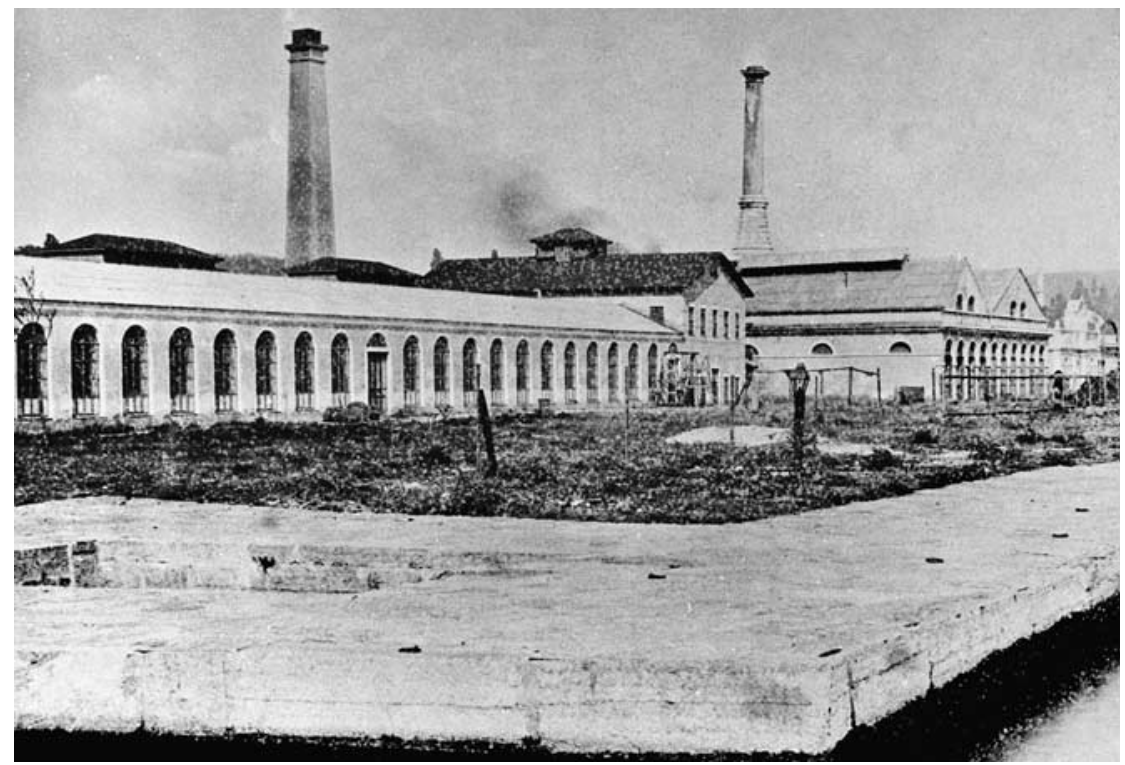

Figure I. Feshane in the late nineteenth century.

From the collection of the German Archaeological Institute in Istanbul (Inst. Negativ-Nr. $K B$ I I634). Used with permission.

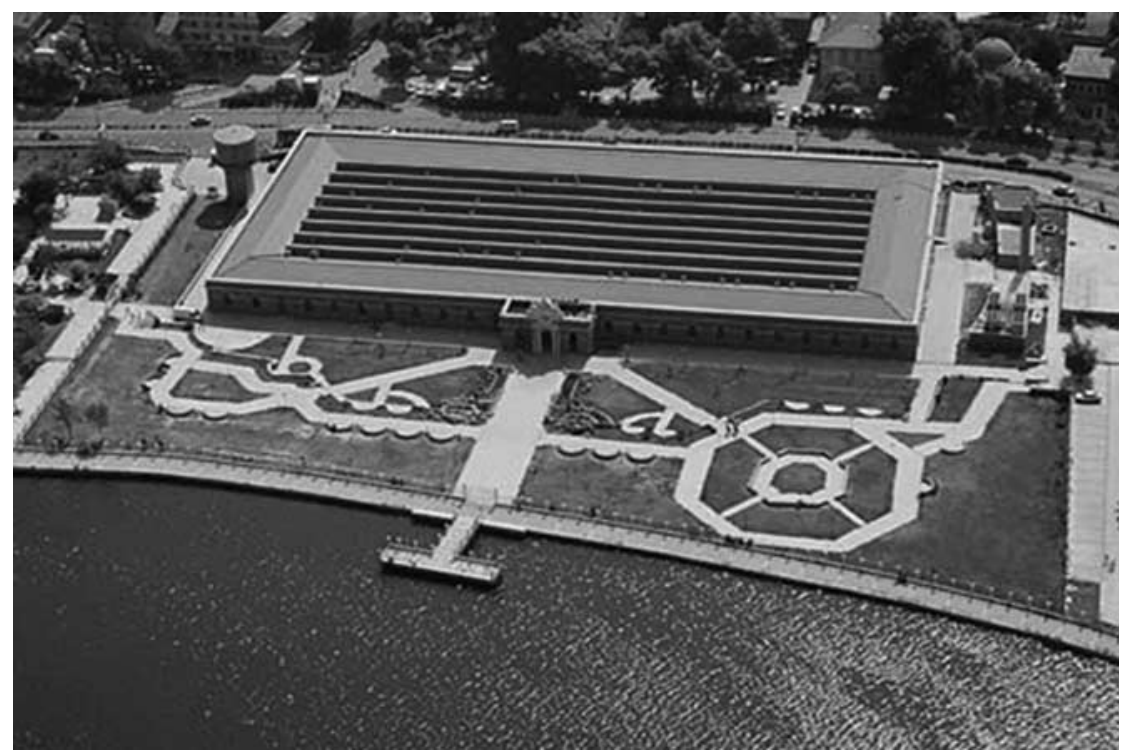

Figure 2. Feshane today.

Downloaded from www.feshane.com.tr 27 September 2008. 
division of labour and its effects on Ottoman historiography, and successfully challenges the notion's validity based upon an Ottoman survey of esnaf in Istanbul from the turn of the nineteenth century. The register in question includes I,859 commercial shops, workshops, and gardens in various locations around the Golden Horn, particularly the Eyüp and Hasköy regions and the west side of the Bosphorus, giving names and titles of artisans, shopkeepers and employees in those locations and names of boatmen and porters working at the piers, as well as of local watercarriers and freelance carpenters.

In his detailed study based on this survey, Kurl claims that regional alliances were crucially important in determining the immigration patterns of artisans into Istanbul, and that the same patterns were equally important in determining the ethno-religious characteristics of shop ownership, occupational specialization, and labour relations in Istanbul. ${ }^{7}$ The relationship between the profile of the labour force and artisanal relations is in accord with Quataert's rejection of a strict ethnic division of labour in his seminal work on Ottoman manufacturing. ${ }^{8}$ Discussing textile production, Quataert asserts that:

$[\ldots]$ it is an inaccurate stereotype to speak of an ethnic or religious division of labor. In the past, writers freely but inaccurately spoke about the inherent, nearly genetically encoded propensity of certain groups for certain kinds of labor. In this so-called "ethnic division of labor", Muslims were seen to be good soldiers and perhaps farmers while Christians of the different ethnicities were understood to be skilled artisans. Such gross characterizations belied the fascinating reality of the Ottoman workforce and, of interest here, the textile workers. While certain ethnic or religious groups did dominate certain forms of labor in particular regions, they did not do so for any industry in the empire as a whole. ${ }^{\text {p }}$

No assessment of the validity of the concept of an ethnic division of labour among Ottoman factory workers has yet been made. Following the previously mentioned findings and views on an ethnic division of labour in Ottoman manufacturing in general, the question whether an ethnic division of labour prevailed, and if it determined working terms and conditions, and particularly remuneration, for Ottoman factory workers, is central to this study. In other words, it is important to determine not only whether ethno-religious characteristics of Ottoman subjects played a role in finding or sustaining an occupation at Feshane,

Profile of the Labor Force in Early Nineteenth-Century Istanbul", International Labor and Working-Class History, 60 (200I), pp. I $25^{-1} 40$, I 26.

7. Kirl, "A Profile of the Labor Force", p. I38.

8. Quataert, Ottoman Manufacturing, p. I 56.

9. Donald Quataert, "Textile Workers in the Ottoman Empire, I650-I922" (paper presented at the conference on "A Global History of Textile Workers I650-2000", International Institute of Social History, Amsterdam, I I-I 3 November 2004), p. I I. 
but also whether ethno-religious characteristics co-determined the level of earnings at Feshane.

In fact, division of labour emerged as an economic term through the rise of factory production. Without a highly specialized labour force to allow for the development of complex skills in production processes, no factory work would have been feasible. The earliest well-known example of division of labour in the literature of economics is from Adam Smith, based on his observations of a pin factory. ${ }^{10}$ In a factory setting based on specialized labour and stages of production, division of labour is the basis of planning, performing, and controlling the whole production process. Therefore, a factory setting and a close reading of available wage ledgers together provide an ideal case study for numerically analysing the validity of an ethnic division of labour for the purposes of this study.

\section{SOURCES FOR THE EARNINGS OF OTTOMAN WORKERS}

A limited number of micro studies, based on surveys and registers, provide a great deal of insight into the Ottoman labour force. However, surveys specific to artisans and craftsmen in the Ottoman Empire are scarce. In European history, documents from guilds provide rich material for quantitative analyses, but unfortunately that is not the case for Ottoman history, ${ }^{\mathrm{II}}$ and to obtain archive sources for manufacturing activity in the Ottoman Empire beyond the control of guilds is even more difficult. ${ }^{12}$

On the other hand, there are detailed surveys and registers on the workforce of organized large-scale industrial production. The Ottoman archives provide rich material on such imperial industrial enterprises as the Imperial Arsenal, ${ }^{\mathrm{I}}$ or the cannon foundry. ${ }^{\mathrm{I}}$ There are too a few archives available of individual industrial enterprises outside the state archives. Quataert's latest monograph on the Zonguldak coalfield is a superb example of the richness of such archives. ${ }^{15}$

Io. Adam Smith, An Inquiry into the Nature and Causes of the Wealth of Nations, R.H. Campbell, A.S. Skinner, and W.B. Todd (eds) (Indianapolis, IN, I98I), I, pp. I4-15.

I I. See Suraiya Faroqhi, "Ottoman Craftsmen: Problematic and Sources with Special Emphasis on the Eighteenth Century", in Suraiya Faroqhi and Randi Deguilhem (eds), Crafts and Craftsmen of the Middle East: Fashioning the Individual in the Muslim Mediterranean (London, $2005)$, pp. 84-I I 8, for a discussion of the limits and possible strategies to re-evaluate sources on Ottoman craftsmen.

I 2. Quataert, Ottoman Manufacturing, pp. 8-9.

I3. See Idris Bostan, Osmanlı Babriye Teșkilâtı: XVII. Yüzyılda Tersâne-i Âmire (Ankara, I992), for a detailed study.

I4. For a recent study on the foundry in the classical age see Gábor Ágoston, Guns for the Sultan: Military Power and the Weapons Industry in the Ottoman Empire (Cambridge, 2005). I 5. Donald Quataert, Miners and the State in the Ottoman Empire: The Zonguldak Coalfield, I822-I920 (New York, 2006). 
However, although there is material on state factories available in the Ottoman state archives, there is no such thing as a monograph on the Ottoman industrial workforce. The principal barrier to that is limited access to the sources consequent upon the currently incomplete catalogues of the vast amount of material there, certainly not because of any lack of documentation. The archive sources used in this article are two of the very few available wage ledgers of Feshane from thei 870 s. $^{16}$

\section{FESHANE WORKERS ON WAGE LEDGERS}

The Feshane wage ledgers are not only important records of factory employees' earnings, they also convey detailed information about the organization and control of the production process there. In the ledgers, factory employees are grouped according to task, delineating the departmental organization of Feshane. The wage ledger HH I9I I is a representative example of newly introduced methods of controlling the production process and covers the period between I 3 February and I 2 March i 876.

We do not have detailed technical information regarding production processes at Feshane, ${ }^{17}$ but the departmental organization given in wage ledger HH igis I reflects actual production. The present study benefits from the valuable information contained in another recent study of the fez industry, ${ }^{18}$ in Austria, which gives an insight into the organization of fez production in Bohemia. In this article, the focus will be on the possible role of the ethn-oreligious characteristics of Feshane's employees in determining their earnings, rather than on the techniques of production. Nevertheless, the main features and steps of production must be considered in order to be able to place the workers and their functions in context in their various departments within the factory.

Feshane produced a variety of goods, such as cloth and carpets, in addition to fezzes. Despite such variety, the main raw material of all final products was sheep fleeces. As the first step in production, fleeces were sorted and classified, after which they were spun into thread and then either woven into fabrics or carpets in the factory by male workers, or put

ı6. BOA, HH ı9ı I and HH ı8324, BOA (Başbakanlık Osmanlı Arşivleri) [Ottoman State Archives in Istanbul].

17. There is an early account from I 838 with limited technical detail on fez production in Julia Pardoe, The City of the Sultan; and Domestic Manners of the Turks, in I836, 3 vols (London, I838), III, pp. I77-I84. Tezcan too gives brief information on the production process: Hülya Tezcan, "Fes", Türkiye Diyanet Vakfi İslam Ansiklopedisi, I 2 (1995), pp. 4I 5-4I6.

I8. I am indebted to Markus Purkhart for providing me with a copy of his thesis, which provides rich technical detail on fez production. Markus Purkhart, "Die Österreichische Fezindustrie" (unpublished Ph.D. dissertation, Vienna University, 2006), pp. I42-1 56. 
out to female knitters, whose work was then collected and worked into fezzes at the factory. Every individual worker, male and female, had a specific entry in the wage ledgers, in which the name, number, task, and earnings of that worker were recorded, although the different departments were not numbered in the wage ledger.

Three types of employee remuneration were in use at Feshane: monthly wages, daily payments, and piecework payments. Clerks, public servants, and instructors received their wages monthly, as did workers at the Izmit branch of Feshane, shopkeepers in Feshane's retail shops, and retired employees. The rest of the male workforce was paid either daily or at piecework rates. Apart from the small number of women who knitted the Sultan's fezzes, pay to female workers was recorded in separate registers.

\section{COUNTING RELIGIOUS AND ETHNIC AFFILIATIONS OF FESHANE EMPLOYEES}

As previously mentioned, apart from workers' names and occasionally their titles, individual entries gave no information about religious or ethnic affiliation, although there is one exception to that, since black workers were registered distinctly as zenci. ${ }^{19}$ However, apart from one autobiographical family history, there is almost no information about black Ottomans to enable us to comment on their existence at Feshane. ${ }^{20}$ The rest of the employees were registered by name and title only, a lack of information remarkable for the implications it has for the workings of the Ottoman bureaucratic mind.

Ethno-religious characteristics of employees were not criteria noted by the state, but to explore the religious or ethnic profile of the factory workforce, and its possible implications for the division of labour within the factory, the religious and ethnic affiliation of workers should be known.

Factory employees' titles provide limited hints of religious affiliation. Religious titles such as Hacı (حاجى), Hafiz, Seyid, and Dede are clear designators of Muslim faith, whereas a different spelling of Hacı (هاجى) states that the title-bearer is a Christian. Nevertheless, titles are unreliable indicators. Although it has been generally accepted that those who bore the title $\mathrm{Hact}$ had either been on pilgrimage to Mecca or Jerusalem, new research, including studies of the wage ledgers from Feshane, shows that that might not have been universally true. At Feshane there were several ordinary workers earning low incomes who bore the title $\mathrm{Hact}$, but it is highly questionable whether they could have possessed the financial

19. Negro in Turkish.

20. Mustafa Olpak, Kenya-Girit-İstanbul: köle kiynsindan insan biyografileri (Istanbul, 2005). 
means to cover the relatively high cost of pilgrimage. Similarly, we cannot assume that several Seyids working at Feshane were indeed descendents of the prophet Muhammad. Status titles such as A $\breve{g a}, B e \breve{g,}$ Efendi, or Hoca, on the other hand, are even less useful as classification, ${ }^{2 \mathrm{I}}$ since $A \breve{g a}, B e \breve{g}$, and Efendi were used interchangeably in the Feshane wage ledgers for the same individuals. In sum, religious or status titles of Feshane employees are not useful markers for religious affiliation nor for position in the social hierarchy.

As a result, only the names of employees can be used to indicate their ethno-religious affiliations. However, before creating workable name lists, ethno-religious categories have to be defined. In this present attempt, religion is the primary category, therefore the Muslim employees will be considered as a single group irrespective of their religious subcategories (Sunnis, Alawis, for example) or their ethnic heterogeneity (Turks, Kurds, for instance). On the other hand, non-Muslim employees of the factories can be more easily divided into three subcategories according to names: Armenians, Orthodox Christians, and Jews. Assigning Armenians a single category, without taking into consideration the confessional differences among the Armenian community (Catholic, apostolic, evangelical), is again necessary due to the limited information imposed by the lack of available sources.

It should also be stated that defining a single category for Orthodox Christians, as a confessional group, could understate ethnic subcategories and their respective importance to that group. While it is evident that Greek subjects constituted the majority of Orthodox Christians in the factory workforce, it is impossible to differentiate Bulgarian subjects from Greeks simply by their names, and it is problematic to use Greeks in the I 870 s in Istanbul as an ethnic, and especially as a national, category. The last subdivision of the non-Muslim workforce, Jews, is somewhat less difficult due to its relative ethnic and religious homogeneity. Hence, the ethno-religious categories for factory employees are: (a) Armenians; (j) Jews; (m) Muslims; (oc) Orthodox Christians; and (x) unknown both for the undeciphered and ambiguous names.

Onomastics, which is the study of the origin, history, and use of proper names, was the single method available in preparing the list of names and corresponding ethno-religious categories. The fact that Ottoman subjects did not use nor even have family names in the nineteenth century makes it difficult to identify individuals using only first names. Nevertheless, using onomastic methods it is still possible to sketch the ethno-religious 
composition of the Feshane workforce. Despite the fact that onomastic literature on subjects of the Ottoman Empire is almost non-existent, there are numerous websites listing names of Armenians, although the reliability of them is highly questionable, and available lists for Orthodox Christians are even more limited. Muslims are relatively easier to identify for me, thanks to my own familiarity with Muslim names and additional markers such as religious titles, the previously mentioned difference in writing $\mathrm{Hact}$ being one helpful indicator. Moreover, status titles such as $\mathrm{Aga}$, Efendi, and Beg belonged almost without exception to Muslims. On the other hand, however, differentiating non-Muslim subjects from each other and assigning ethno-religious affiliations based solely upon their first names is a very difficult task. Given the few available name lists, individuals and institutions had to be consulted for help and guidance. ${ }^{22}$

In total 160 names were identified in the wage ledger $\mathrm{HH}$ i9 $5 \mathrm{I}$ in their respective ethno-religious categories. In the following, the earnings of Feshane employees will be examined according to their ethno-religious characteristics. ${ }^{23}$ In the wage ledger 506 employees are listed. There were 388 Muslim, 89 Armenian, 7 Orthodox Christian and 2 Jewish male employees at Feshane. The ethno-religious affiliation of the remaining 20 employees could not be confirmed from the limited information available. The percentage distribution can be seen in Figure 3.

The two entries under the Jewish name Solomon are for a person or persons cleaning two different types of fleece, but it is likely that there was only one Jewish employee and that he was either a subcontractor or the head of a group performing that task. There was no other Jewish subject working at Feshane. Therefore, it is not feasible to make any comment on the Jewish employees, except that Jewish subjects did not constitute a considerable part of the workforce. The number of Orthodox Christians is also extremely low. Even if we assume that all the unknown

22. Without the help and expert knowledge of Dimitri Theodoridis, it would have been impossible even to attempt to quantify ethno-religious information through names. Ani Yazmaciyan not only provided a short but extremely helpful list of Armenian names: Ermeni Patrikliği, Ajanda (Istanbul, 2002), but also helped to identify numerous Armenian employees. Elias Kolovos's sound knowledge and Greek and Bulgarian name lists were crucially important. Without the help of Yorgo Benlisoy, the publication containing a detailed list for Orthodox

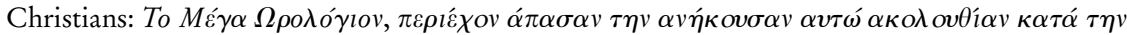

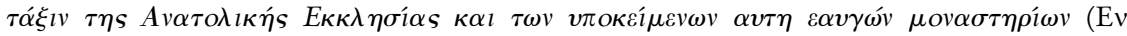

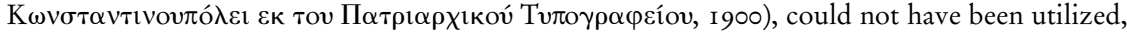
nor, similarly, without the guidance of Vagharshag Seropyan, could a publication of the Armenian Patriarchate in Istanbul from I90I which includes a detailed name list (Cunupduul

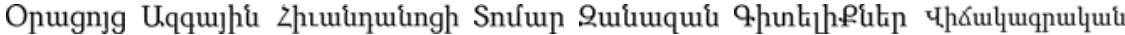
Stintluntphulutp). Lastly, without the generous help and expertise of his Excellency the Patriarch Mesrop II, numerous question marks in the name lists could not have been resolved. 23. The following calculations were made with a spreadsheet calculation program after the wage ledger data had been entered and adjusted accordingly. 


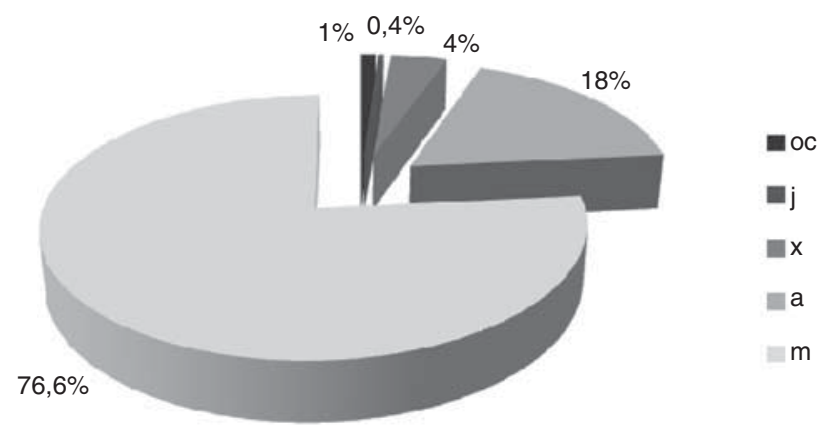

Figure 3. Ethno-religious composition of Feshane's male employees (in percentages), I 3 February-I 2 March I 876.

HH I9ISI.

employees were Orthodox Christians, they would constitute only 5 per cent of the total workforce.

Before commenting on the percentage of Orthodox Christians at Feshane, we should discuss the category of unknowns. Although there are i 8 names either ambiguous or illegible, the total number of times those names appear in the ledger is 20 , or only 4 per cent of the total 506 entries. That marginal ratio is crucially important in relation to the reliability of this numerical analysis, so it can be claimed that the dataset tailored along the lines of the ethno-religious categories defined for this study is statistically significant for Muslims and Armenians.

Although Orthodox Christians constituted a very important part of the empire's and of Istanbul's population, they were extremely underrepresented in Feshane's male workforce. It is beyond doubt that Orthodox Christian subjects were a substantial and active part of Ottoman manufacturing, and there were many Bulgarian manufacturers in the capital. ${ }^{24}$ Why was there such a drastic underrepresentation of Orthodox Christians at Feshane? The most plausible explanation is political. It is generally agreed that the total number of Orthodox Christians in the service of the state fell sharply in the aftermath of Greek independence, ${ }^{25}$ but all the same there are some counterexamples: in the Ottoman Bank, recruitment policies and the ethnic profile of employees did not undergo major changes during the nineteenth century, and not indeed until I9 г I. ${ }^{26}$

24. For a general assessment of the Bulgarian presence in Istanbul prior to 1878 see Yeorgios Kiutuçkas, “I 878'e Kadar İstanbul'daki Bulgar Cemaati”, in Pinelopi Stathis (ed.), 19. yüzynl İstanbul'unda Gayrimüslimler (Istanbul, 1999), pp. 36-5 I; for figures on Bulgarian artisans in Istanbul, see pp. 38-39. 25. Carter Findley, "The Acid Test of Ottomanism: The Acceptance of Non-Muslims in the Late Ottoman Bureaucracy", in Benjamin Braude and Bernard Lewis (eds), Christians and Jews in the Ottoman Empire: The Functioning of a Plural Society, 2 vols (New York, I982), I, p. 34I. 26. Edhem Eldem, A History of the Ottoman Bank (Istanbul, 1999), pp. 430-435. 
If we consider that Feshane was not merely an industrial but also a military-political setting, the limited number of Orthodox Christians can be better understood. Unfortunately, there was no state textile factory prior to Greek independence, so it is rather difficult to assess that hypothesis. Employment policies at the Imperial Arsenal and the canon foundry in the same period could provide an insight into the matter, but unfortunately those examples have not yet been studied in detail. On the other hand, the extremely high percentage of female Orthodox Christians working for Feshane from their homes is striking. Non-Muslim knitters constituted almost the whole female workforce, and only approximately 2 per cent of fezzes were knitted by Muslim female knitters in the same period. In contrast to the situation with male workers, the distribution of jobs between Armenian and Orthodox Christian knitters was almost even. ${ }^{27}$

Such a marked discrepancy between the percentage of male and female Orthodox Christians in the workforce again tends to confirm the hypothesis that male Orthodox Christians were not preferred in Ottoman military industrial enterprises. The emphasis there cannot have been on the industrial policy of the Ottoman state, but rather on military sentiments about Orthodox Christians. Therefore, it would be plausible to assume that military concerns were influential in employment policies in Ottoman state factories in the nineteenth century.

Naturally, the wage ledger provides not only the number of workers but their individual earnings too. If we exclude the two entries for Solomon, the average earnings of Feshane employees can be computed as follows: Feshane employees' overall average monthly earnings were 350 kuruss for the one month period covered by the wage ledger. That figure itself is not very significant, being the arithmetic average of the monthly earnings of 506 employees, irrespective of individual status, qualifications, or ethno-religious characteristics. However, the fact that the average monthly earnings of Muslim, Armenian, and Orthodox Christian employees do not diverge substantially from the overall average indicates that ethno-religious characteristics alone were not a significant factor in determining those employees' earnings. A more accurate assessment of the effects on wage levels of ethnoreligious characteristics should be based on an intradepartmental comparison of employees' earnings at Feshane, instead of on overall averages.

There were no non-Muslim employees at the administrative level in the factory, and, apparently, non-Muslim subjects did not or could not acquire high-earning public servant status at Feshane. Not surprisingly, in the first department, administration, the average wage was the highest in the factory, and the second and third departments too, similarly performing 


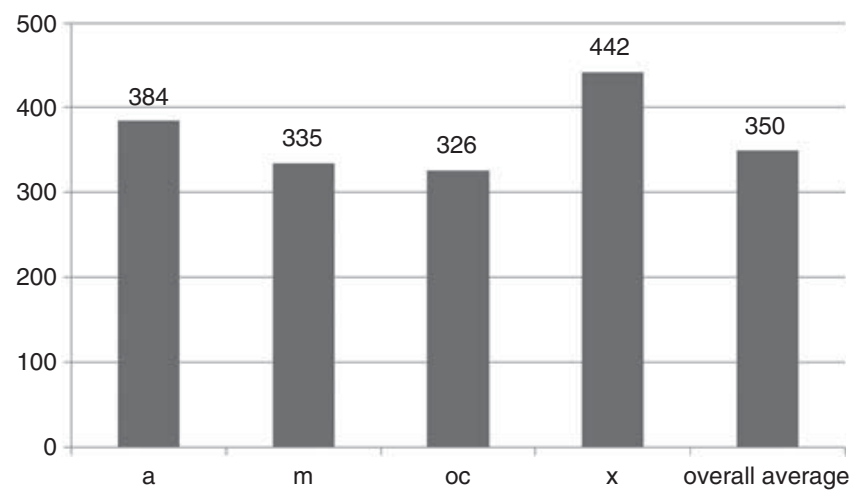

Figure 4. Average monthly earnings ${ }^{28}$ of male Feshane workforce, I3 February-I2 March i 876. HH I9ISI.

administrative tasks and manned by public servants, had relatively high wage averages. Moreover, in the higher echelons, which consisted primarily of Muslims, the total earnings of individual employees (in kuruş) was higher, and their salaries were paid monthly. However, a closer look at wage levels in separate departments of the factory is necessary for a better understanding of earnings levels. ${ }^{29}$

If we take into consideration that Muslim employees significantly outnumbered non-Muslims at Feshane in the given period, it is not surprising that they outnumbered them in individual departments as well. Only Department 27 had an unusual distribution, among its warp workers: at least eight of the twelve workers were non-Muslim (seven Armenians and one Orthodox Christian) working alongside three Muslims and one unidentified worker. Nevertheless, the fact that some of the departments consisted solely of non-Muslims is striking. In addition to the three administrative departments earning relatively high wages mentioned previously, there were five larger departments, which employed Muslims exclusively: Departments 16, 18, 20, 22 and 38.

There was no department with more than two employees at Feshane which employed non-Muslim males exclusively, a finding which challenges the concept of ethnic division of labour. The fact that most departments employed both Muslims and non-Muslims implies that there was no strict division of labour based on religious affiliation. On the other hand, non-Muslims somehow monopolized the higher-paid positions in several departments. If religion is not the categorical and decisive criterion 
responsible for the division of labour in Feshane, what can be the reason for such a distinct separation? Possible explanations are clientship, and group alliances among Feshane employees. However, the wage ledger does not provide answers to those questions.

Obviously, there was more than one dynamic of alliances and competition interacting in Feshane and the outcomes of those struggles codetermined the working conditions and pay of employees. Groups of workers probably banded together to defend themselves and their interests against other groups. Religion was doubtless a unifying factor, yet it cannot have been the only reason for group building, nor the single basis for alliances at Feshane. Wage ledgers clearly disprove such a hypothesis: religion was surely important, but was not the sole determinant in the framework observed.

Istanbul was a magnet for immigrants from all Ottoman territories, so regional alliances should be considered. Migrants constituted the major part of the industrial workforce in the capital, including Feshane. As a result, the dynamics of migration must not be overlooked when we look for explanations for group alliances among Feshane employees.

\section{NETWORKS OF MIGRATION}

As we have seen, the Feshane wage ledgers do not convey much personal information about employees. Most noticeably after a thorough factory inspection and subsequent reorganization in $187 \mathrm{I}$, modern methods of bookkeeping were introduced. ${ }^{30}$ The clearest impact on the labour side at Feshane made by new methods of registering and controlling production, was assigning individual employee numbers to each worker. There were very few exceptions to the new rule and the change definitely increased the accuracy of identifying and surveying the performance of individual workers.

Unfortunately, the new system also made superfluous the detailed personal information about individual workers which for historians has proved so helpful, in some cases even absolutely necessary in identifying and differentiating workers from each other. In the absence of photographs or detailed personal files, the state administration had also been accustomed to register individual's personal information, such as home town, or physical appearance, stature, facial hair growth, and so on. There is only one wage document available for this study containing that sort of detail about Feshane employees, the undated ledger ( $\mathrm{HH}$ i 8324) which notes the physical appearance, and more importantly the home towns, of some of the Feshane workers. In the following, networks of migration to

30. Kabaday1, "Working for the State in a Factory in Istanbul”, pp. 89-96. 
Istanbul and their repercussions on the ethno-religious distribution of positions in the departments of the factory will be assessed based upon analysis of the home towns of some Feshane workers.

Feshane's departmental organization in this document differs from the organization represented in the wage ledger given in Appendix I. The total number of departments in which male employees were remunerated is thirty-four instead of the thirty-nine in $\mathrm{HH}$ igI $5 \mathrm{I}$. The most obvious difference between the two documents is the fact that employees did not yet have their individual worker numbers in the undated register, which leads me to believe that it was compiled before the reorganization. There are, in fact, numerous other indications that it was compiled then. For instance, there is one department listed as the clerks of the numbering office. The duty of one of those scribes is given as assigning numbers.

The undated document individually lists 280 workers in 28 departments but for 7 other departments ${ }^{3 \mathrm{I}}$ gives only the total number of employees in each department and does not list individual workers. If the number of employees in those 7 departments (94) is added to the 280 employees listed individually, the total number of employees at Feshane accounted for in the ledger is 374,6 employees short of the 380 employees reported in the final report of the i 87 I reorganization at Feshane..$^{32}$ As a result, it is plausible that this detailed list of workers was compiled for the purposes of the reorganization. That total number reflects a substantially smaller workforce at Feshane than reported for the period between I 3 February and I 2 March I 876 in wage ledger HH I9 5 I, which gives 506 as the total number of employees. Such an increase over 5 years is not surprising since it is noted in the final report that the number of qualified personnel would be increased after the reorganization.

The fact that the register does not provide individual information about 94 of 374 employees makes the ethno-religious distribution of the workforce of the sample from i87i scarcely comparable quantitatively with the one from 1876 . Calculations regarding average wages based on ethno-religious categories could also be misleading. However, the ethnic composition of those 280 employees does give a general idea of the ethnoreligious composition of that limited sample. In I87 I Muslims, with I 57 workers, were the largest ethno-religious group, followed by the 103 Armenians. With only 4 workers, Orthodox Christians constituted a very marginal group, and there were a total of 6 European engineers from Great Britain and France, and ro employees whose names could not be interpreted.

31. At this point it should be noted that the original wage registers do not have department numbers, but simply list the names of the employees in groups which have been numbered for simplicity.

32. HH.FSH 9/27, pp. 5-8. 


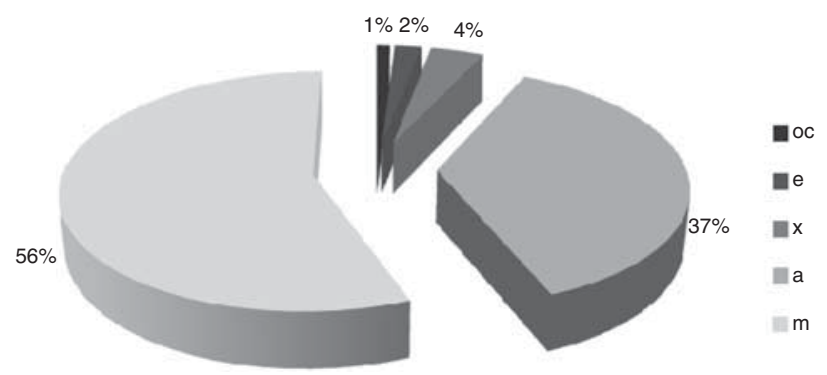

Figure 5. Ethno-religious composition of Feshane's male employees (in percentages) in $187 \mathrm{I}$. HH 18324 .

The general outcomes of the figures for i 87 I can be summed up very briefly as follows: the male workforce of Feshane was mainly composed of Muslims; among non-Muslims, Armenians were over-represented, while Orthodox Christians were extremely under-represented.

It is remarkable that the wage ledger documents the home towns of 2 I 2 of the total 280 Feshane employees listed in it. Not surprisingly, most of the employees were from Istanbul, and it is likely that most of the clerks too, and foremen of the various departments for which home towns are not given, were from Istanbul. Therefore, the 7 I employees listed as being from greater Istanbul most probably represent a conservative estimate. Individuals not from Istanbul were either Muslims or Armenians from all over the Ottoman Empire, from remote places in the Balkans to the border towns of eastern Anatolia. ${ }^{33}$

Such a wide geography of migration challenges the assumption of low social mobility for rural Ottoman populations. Approximately half of the workers considered here were Armenian, which is a high percentage but is not surprising considering the general over-representation of Armenians at Feshane. The second largest group of employees were from Ankara, and the significant concentration of Armenians among them is extraordinary, indicating a possible migration network. Armenians from Ankara were working in sixteen of the total of thirty-four departments at Feshane, but their highest concentration was in the cloth glossing and printing department. Of the seventeen employees working there, eleven were Ankara Armenians. All the employees in that department were non-Muslim, and sixteen of them bore Armenian names and were from Ankara or Istanbul, meaning that it is likely that a network of Armenians had developed.

The third largest group of workers was from Opar, quite a small town close to Görice in modern Albania. A total of sixteen workers from there 


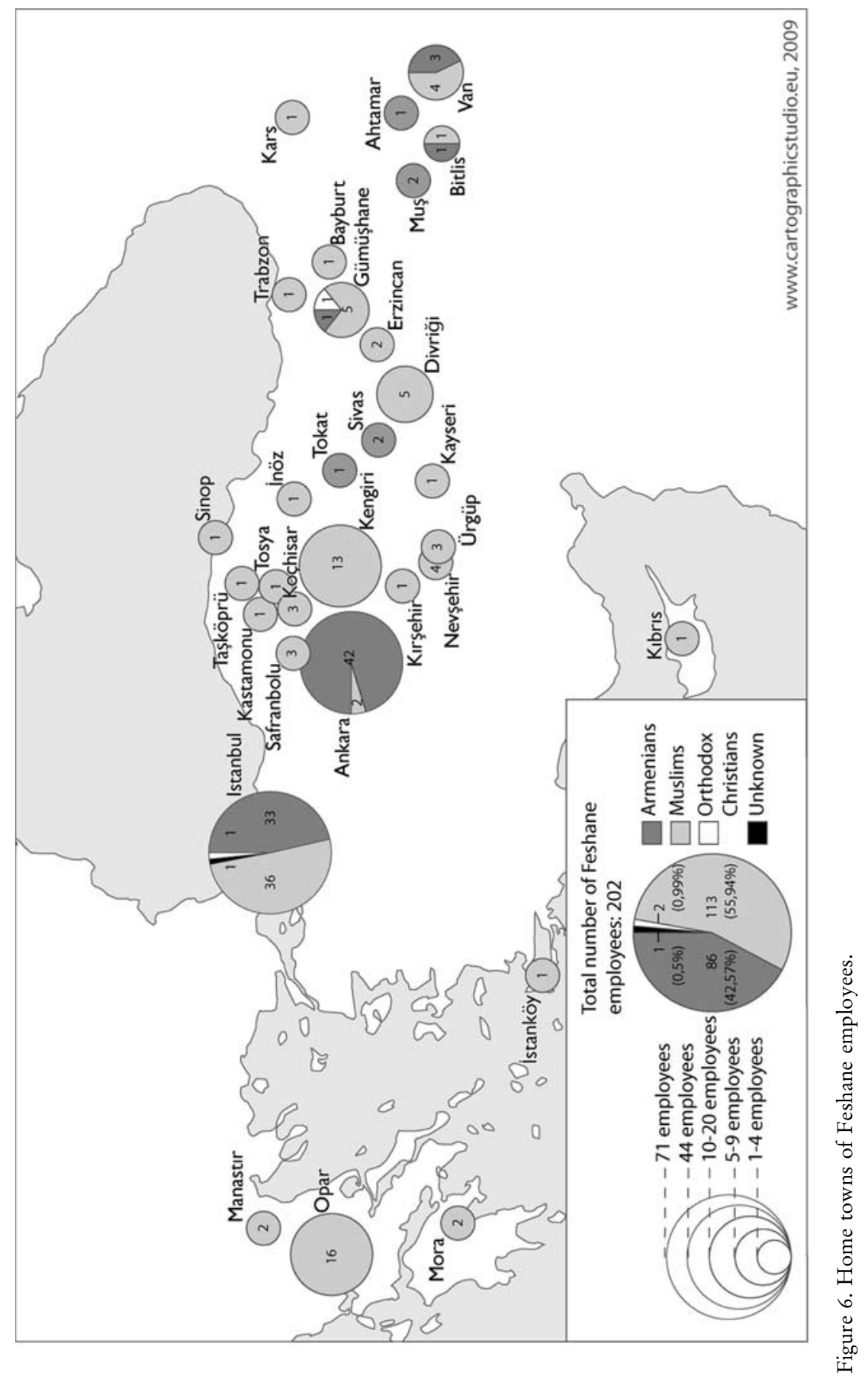


were employed in six different departments, and all were Muslim. Seven Muslims from Opar were employed in the fez glossing department, but since that was one of the largest departments and employed thirty-two workers they were not a major part of the department's workforce, although that was where the greatest number from Opar worked. Another department employed fifteen workers, four of whom were from Opar, representing a third of that department's workforce. Such a considerable concentration of workers from Opar in two departments indicates not only solidarity among people from same home town, but also the existence of networks of economic migration.

If we disregard the exceptions of Ankara, Van, and Gümüşhane, a migration pattern emerges that can be traced along ethno-religious lines. Places which provided more than two migrant workers were Opar, Kengiri, Divriği, Koçhisar, Ürgüp, Safranbolu, and Nevşehir. Workers from all those places were Muslim, without exception. Bonds of shared locality were probably strong enough to organize a network at Feshane among co-religionists, although one possible explanation for the fact that workers from Istanbul and Ankara do not fit into that pattern is that there might have been multiple networks developed within different ethnoreligious groups of workers from the same district.

\section{CONCLUSION}

In this study, the role of the ethno-religious characteristics of Ottoman subjects in their finding of jobs, performing their tasks, and earning money at Feshane has been examined based on Feshane's wage ledgers. It should be stated again here that Feshane's administration did not consider ethno-religious characteristics of Ottoman subjects in registering their performance and respective remuneration, for according to Ottoman official custom the ethnicity of employees was not a separate official category there. As a result, the ethno-religious categories created along the lines of the Ottoman millet system - Armenian, Orthodox Christian, and Jewish - are in fact, for the purposes of this inquiry, ahistorical. The quantitative analysis attempted here shows that ethno-religious categories alone explain neither wage differences nor the division of labour. A close look at the departmental distribution of workers suggests that ethnic division of labour was not the practice at Feshane.

On the other hand, gender and religion were definitely important criteria which determined for Ottoman subjects their prospects of being employed at Feshane. Gender alone determined whether Ottoman subjects might be employed at Feshane, or could work for the factory from their homes. Religion too was important. For non-Muslim men it was a barrier to their ascent to the higher echelons at Feshane, while for Muslim women it was difficult to obtain any work there. 
Gender, religion, and ethnicity were certainly influential in determining the prospects of Ottoman subjects as employees at Feshane, not as officially recognized categories but in their interaction with each other. For instance, the fact that male Orthodox Christians could hardly acquire jobs at Feshane does not imply that Orthodox Christians were at a disadvantage because of their religion, since at the same time Orthodox Christian women were favoured as fez knitters. The importance of ethno-religious characteristics can be observed as well in patterns of migration. Regional alliances were considerably important in network building and acquiring jobs at Feshane and ethno-religious solidarity probably functioned as a second layer of cooperation and unity among migrants. In other words, the findings of this study suggest that regional alliances co-determined the chances of Ottoman workers in labour recruitment and working conditions, and likewise for the industrial workforce at the factory level. 
Appendix I. Total number and average monthly earnings ${ }^{34}$ of Feshane employees in their departments, and respective to ethno-religious characteristics, 13 February-2 March 1876

\begin{tabular}{|c|c|c|c|c|}
\hline Departments & $\begin{array}{c}\text { Ethno-religious } \\
\text { characteristics }\end{array}$ & $\begin{array}{l}\text { Total no. of } \\
\text { employees }\end{array}$ & $\begin{array}{l}\text { Average } \\
\text { earnings }\end{array}$ & $\begin{array}{l}\text { Total } \\
\text { Earnings }\end{array}$ \\
\hline \multirow[t]{2}{*}{1 Regular public servants } & & 18 & 913 & 16430 \\
\hline & M & 18 & 913 & 16430 \\
\hline \multirow[t]{2}{*}{2 Depot public servants } & & 14 & 489 & 6850 \\
\hline & M & 14 & 489 & 6850 \\
\hline \multirow[t]{2}{*}{3 Miscellaneous public servants } & & 11 & 389 & 4280 \\
\hline & M & 11 & 389 & 4280 \\
\hline \multirow[t]{4}{*}{4 Instructors } & & 26 & 708 & 18415 \\
\hline & $\mathrm{A}$ & 10 & 865 & 8650 \\
\hline & M & 14 & 547 & 7660 \\
\hline & $\mathrm{X}$ & 2 & 1053 & 2105 \\
\hline \multirow{3}{*}{$\begin{array}{l}5 \text { Public servants at } \\
\text { Babariye }^{35} \text { branch }\end{array}$} & & 43 & 224 & 9638 \\
\hline & A & 1 & 360 & 360 \\
\hline & M & 42 & 221 & 9278 \\
\hline \multirow{2}{*}{$\begin{array}{l}6 \text { Coarse and fine fleece } \\
\text { separators }\end{array}$} & & 2 & 863 & 1725 \\
\hline & $\mathrm{J}$ & 2 & 863 & 1725 \\
\hline \multirow[t]{3}{*}{7 Carpenters } & & 10 & 435 & 4346 \\
\hline & A & 5 & 409 & 2045 \\
\hline & M & 5 & 460 & 2301 \\
\hline \multirow[t]{3}{*}{8 Steamers } & & 6 & 342 & 2054 \\
\hline & $\mathrm{A}$ & 2 & 344 & 687 \\
\hline & M & 4 & 342 & 1367 \\
\hline \multirow[t]{4}{*}{9 Ironworks } & & 18 & 417 & 7501 \\
\hline & $\mathrm{A}$ & 4 & 277 & 1109 \\
\hline & M & 10 & 472 & 4715 \\
\hline & $\mathrm{X}$ & 4 & 419 & 1677 \\
\hline \multirow[t]{4}{*}{10 Sakat knitters } & & 8 & 255 & 2041 \\
\hline & A & 1 & 312 & 312 \\
\hline & M & 6 & 236 & 1417 \\
\hline & $\mathrm{X}$ & 1 & 312 & 312 \\
\hline \multirow{5}{*}{$\begin{array}{l}11 \text { Dinkhane workers at } \\
\text { Izmit }\end{array}$} & & 16 & 378 & 6050 \\
\hline & A & 5 & 340 & 1700 \\
\hline & $\mathrm{M}$ & 9 & 411 & 3700 \\
\hline & Oc & 1 & 450 & 450 \\
\hline & $\mathrm{X}$ & 1 & 200 & 200 \\
\hline \multirow[t]{3}{*}{12 Bobbin wrappers } & & 4 & 246 & 983 \\
\hline & A & 1 & 200 & 200 \\
\hline & $\mathrm{M}$ & 3 & 261 & 783 \\
\hline
\end{tabular}

34. Figures are rounded up and given in kuruş.

35. Words in italics are Turkish terms which could not be translated; the question marks denote words which were illegible. 


\begin{tabular}{|c|c|c|c|c|}
\hline Departments & $\begin{array}{l}\text { Ethno-religious } \\
\text { characteristics }\end{array}$ & $\begin{array}{l}\text { Total no. of } \\
\text { employees }\end{array}$ & $\begin{array}{l}\text { Average } \\
\text { earnings }\end{array}$ & $\begin{array}{l}\text { Total } \\
\text { Earnings }\end{array}$ \\
\hline \multirow{3}{*}{$\begin{array}{l}13 \text { Fine power loom } \\
\text { workers }\end{array}$} & & 7 & 305 & 2137 \\
\hline & $\mathrm{A}$ & 1 & 390 & 390 \\
\hline & $\mathrm{M}$ & 6 & 291 & 1747 \\
\hline \multirow{3}{*}{$\begin{array}{l}14 \text { Fine yarn ward meydance } \\
\text { workers }\end{array}$} & & 12 & 315 & 3775 \\
\hline & $\mathrm{A}$ & 5 & 318 & 1591.5 \\
\hline & M & 7 & 312 & 2183.5 \\
\hline \multirow[t]{3}{*}{$\begin{array}{l}15 \text { Fine yarn ward comb } \\
\text { workers }\end{array}$} & & 6 & 666 & 3998.6 \\
\hline & $\mathrm{M}$ & 5 & 644 & 3221.6 \\
\hline & $\mathrm{X}$ & 1 & 777 & 777 \\
\hline \multirow[t]{2}{*}{16 ? weavers } & & 8 & 229 & 1834.15 \\
\hline & $\mathrm{M}$ & 8 & 229 & 1834.15 \\
\hline \multirow[t]{2}{*}{17 Bobbin wrappers } & & 1 & 144 & 144 \\
\hline & M & 1 & 144 & 144 \\
\hline \multirow[t]{2}{*}{18 Stocking knitters } & & 7 & 211 & 1474 \\
\hline & M & 7 & 211 & 1474 \\
\hline \multirow{3}{*}{19 White glossing } & & 33 & 282 & 9311.5 \\
\hline & $\mathrm{A}$ & 1 & 494 & 494 \\
\hline & M & 32 & 276 & 8817.5 \\
\hline \multirow[t]{2}{*}{20 Kopta makers } & & 19 & 218 & 4138.75 \\
\hline & M & 19 & 218 & 4138.75 \\
\hline \multirow[t]{3}{*}{21 Fez dye house } & & 17 & 256 & 4346 \\
\hline & $\mathrm{A}$ & 2 & 260 & 520 \\
\hline & M & 15 & 255 & 3826 \\
\hline \multirow[t]{2}{*}{22 Red glossing } & & 30 & 265 & 7947.5 \\
\hline & M & 30 & 265 & 7947.5 \\
\hline \multirow[t]{3}{*}{23 Coarse power loom } & & 5 & 252 & 1260.5 \\
\hline & A & 1 & 238 & 237.5 \\
\hline & M & 4 & 256 & 1023 \\
\hline \multirow[t]{3}{*}{24 Coarse yarn ward } & & 6 & 232 & 1393 \\
\hline & $\mathrm{A}$ & 1 & 312 & 312 \\
\hline & $\mathrm{M}$ & 5 & 216 & 1081 \\
\hline \multirow[t]{4}{*}{25 Coarse yarn combers } & & 16 & 281 & 4494.4 \\
\hline & A & 1 & 384 & 384.4 \\
\hline & M & 14 & 279 & 3910 \\
\hline & $\mathrm{X}$ & 1 & 200 & 200 \\
\hline \multirow[t]{3}{*}{26 Coarse yarn shapers } & & 9 & 486 & 4377.15 \\
\hline & M & 8 & 475 & 3798.85 \\
\hline & Oc & 1 & 578 & 578.3 \\
\hline \multirow[t]{5}{*}{27 Warp workers } & & 12 & 212 & 2541.5 \\
\hline & $\mathrm{A}$ & 7 & 192 & 1345.5 \\
\hline & $\mathrm{M}$ & 3 & 217 & 649.75 \\
\hline & $\mathrm{Oc}$ & 1 & 224 & 224.25 \\
\hline & $X$ & 1 & 322 & 322 \\
\hline
\end{tabular}


(Continued)

Departments Ethno-religious Total no. of characteristics employees

Average Total

28 Warp glue workers

29 Reed and thimble measure

M

$\mathrm{X}$ makers

30 Weavers' ward meydanc workers

31 Weavers' ward

32 Carpet weaving

$\mathrm{X}$

M

$\begin{array}{rrr}6 & 243 & 1460 \\ 5 & 230 & 1148 \\ 1 & 312 & 312 \\ 2 & 337 & 673\end{array}$

33 Dink and şardun

A

M

Oc

$\mathrm{X}$

A

$\mathrm{Oc}$

A

$\mathrm{M}$

34 Coarse cloth dye house

A

M

Oc

$\mathrm{X}$

35 Coarse cloth ?

A

M

36 Coarse cloth reel

37 Female knitters of imperial fezzes

A

M

A

Oc

38 Shopkeepers

M

39 Retired

A

Grand Total

M

1

1

3

3

51

24

23

1

3

2

1

1

9

3

5

1

19

4

11

1

3

3

2

1

8

1

7

4

$365 \quad 365$

$308 \quad 308$

$247 \quad 740$

$247 \quad 740$

$396 \quad 20197$

$\begin{array}{ll}410 & 9847.25\end{array}$

$387 \quad 8894.75$

$275 \quad 275$

$393 \quad 1180$

$288 \quad 576$

$288 \quad 288$

$288 \quad 288$

$298 \quad 2681$

$250 \quad 750$

$311 \quad 1556$

$375 \quad 375$

$253 \quad 4811$

$261 \quad 1044.5$

$224 \quad 2464.5$

$230 \quad 230$

$357 \quad 1072$

$244 \quad 733$

$204 \quad 408$

$325 \quad 325$

$237 \quad 1898.5$

$247 \quad 247$

$236 \quad 1651.5$

$240 \quad 960$

$240 \quad 720$

$240 \quad 240$

$368 \quad 5515$

$368 \quad 5515$

$164 \quad 3276$

$175 \quad 525$

$162 \quad 2751$

$350 \quad 177006.55$

Source: HH igr 5 I. 